\title{
Recruiting and Job Search Technologies in the Age of Internet
}

\author{
Sergey Roshchin \\ Vice-rector, Laboratory Head, Laboratory for Labour Market Studies, sroshchin@hse.ru \\ Sergey Solntsev \\ Deputy Laboratory Head, Laboratory for Labour Market Studies, ssolntsev@hse.ru \\ Dmitry Vasilyev \\ Student, International College of Economics and Finance, dmvas2007@gmail.com
}

National Research University Higher School of Economics, 20, Myasnitskaya str., Moscow 101000, Russian Federation

\begin{abstract}
$\mathrm{T}$ This article considers recruiting via the internet as an organizational innovation at Russian companies. Using data from a survey of employers and the Russian Longitudinal Monitor Survey (RLMS)-HSE, we measured the scale of internet-use by employers for recruiting and by employees for job searches, and the factors influencing them. In general, the characteristics of employees and workplaces

match. Amid companies, internet use was more common in the retail sector among privately owned and financially successful firms. The internet was more actively used by workers with higher or specialized education from big cities. Internet searches complement other channels and has become the second most popular channel after searching through relatives and friends.
\end{abstract}

\section{Keywords:}

organizational innovation; Internet; human resource management; job search; recruiting.
Citation: Roshchin S., Solntsev S., Vasilyev D. (2017) Recruiting and Job Search Technologies in the Age of Internet. Foresight and STI Governance, vol. 11, no 4, pp. 33-43. DOI: 10.17323/2500-2597.2017.4.33.43 
$\mathrm{O}$ ver the first few years following the emergence of the internet the range of its users remained rather limited, and its proliferation was quite modest. The internet became generally accessible only in the early 2000s. The explosive development of, and reduced prices for, smartphones and other mobile devices at the end of this decade allowed for the extension of the coverage to users who do not own a computer or a subscription to a wired connection. In 2014, $67 \%$ of the Russian population aged between 15-72 had internet access [Rosstat, 2015a]. Against the background of a growing audience, businesses began to be interested in the internet as well; companies specializing in internet-based activities began to appear. Today practically all medium and large firms use the internet in their daily operations, along with a significant share of small enterprises [HSE, 2016].

One area affected by the development of the internet was the recruitment and job search processes, which are analyzed in this paper. Recruitment and job searches, such as the hiring and job placement stages, includes selecting the best candidates and vacancies, interviewing and other techniques used to assess candidates' abilities, leading to the signing of an employment contract. According to a survey conducted by Boston Consulting Group (BCG) in 2014, about 55\% of people who have changed jobs used the internet to find a new one [Sakurai, Okudo, 2015]. Globally, 33\% of the respondents said they believed this approach was the most efficient and $48 \%$ in Russia share this belief. The authors of the survey note that this attitude prompted companies to make better use of the internet for recruitment purposes.

Recruitment is a key element of companies' HR policies. Their success in finding employees that meet the relevant requirements regarding qualifications, experience, skills, etc. largely determines the results of their overall activities [Jovanovic, 1979]. According to an employers' survey conducted by the Ancor recruiting agency, recruitment, hiring and training remain among the top priorities of Russian companies' HR policies [Ancor, 2014]. The internet allows firms to fill job openings with the best candidates, thus contributing to overall productivity and the achievement of the optimal balance between the employees' qualifications and job requirements [Autor, 2001; Kuhn, 2014]. It provides an example of both the companies' organizational innovations and the innovative behavior of the population alike.

Relatively few studies of recruitment- and job seeking-related issues have been conducted in Russia so far. Studies of approaches to choosing job search techniques could be noted in this context [Roshchin Markova, 2004], along with research on graduates' behavior on the labor market [Naryshkina, 2007] and the role of job seekers' social circles [Yakubovich, 2002; Stuken, 2008]. The subject of recruitment is even more poorly studied. A monograph [Avraamova et al., 2006] based on a survey of 1,500 companies concludes that personal relations remain the main recruitment channel, followed by cooperation with universities and professional communities, while the least popular hiring technique is advertising in the media. Certain related issues such as choosing between outsourcing and retraining one's own staff are analyzed in [Denisova, Lazareva, 2006; Roshchin, Travkin, 2015]; these publications focus on staff training mechanisms.

The authors do not know of any studies on the role the internet plays in job search or recruiting activities in Russia. This paper is the first attempt to measure the extent of internet usage on the Russian labor market, to assess the factors affecting it, and its popularity among employers and job seekers.

\section{The Role of the Internet in the Search for Jobs and Recruitment by Companies}

One consequence of the wide proliferation of the internet was the use of organizational innovations ${ }^{2}$ in companies' recruitment policies, which allowed them to significantly increase the productivity of $\mathrm{HR}$ departments and cut the costs associated with advertising vacancies, the use of specialized software, the collection and processing of job seekers' resumes, and interviewing. This resulted in an extended range of applicants, more efficient screening, and reduced administrative and operational recruiting and hiring costs, which according to the OECD Oslo Manual's terms [OECD, Eurostat, 2005] means organizational innovation. Employers and job seekers use the internet for (1) the publishing of and search for information about job vacancies and job seekers, and (2) communication.

Numerous online services and platforms allow one to advertise job openings and publish job seekers' resumes3:

- specialized websites; the most prominent ones in Russia are HeadHunter.ru (21 million resumes as of June 2016) and SuperJob.ru (17 million resumes) ${ }^{4}$;

- corporate websites advertising job vacancies;

- the public employment service's website (the job database at TrudVsem.ru);

- private recruiting agencies' websites;

\footnotetext{
${ }^{1}$ The survey covered 13,000 people in Australia, Brazil, the UK, Germany, India, Italy, Canada, China, Russia, the US, France, South Africa, and Japan.

${ }^{2}$ For more on the typology of innovations see the Oslo Manual: Guidelines for Collecting and Interpreting Innovation Data [OECD, Eurostat, 2005], which is used in Russia to collect relevant corporate statistics.

${ }^{3}$ A review of the use of various internet-based recruiting tools is presented in [Nakamura et al., 2009]. Changes in the US job seekers' strategies caused by development of the internet are analyzed in [Jansen et al., 2005]
} 
- mass media websites publishing job vacancies;

- internet advertising;

- social networks, specialized (such as LinkedIn) ${ }^{5}$ and general ones such as VK.com, OK.ru, and Facebook.

The internet allows one to significantly simplify and speed up the process of finding jobs/workers, achieve the best match between candidates and vacancies, and extend the range of both the former and latter alike as far as possible. Studies of the US, German, and South Korean labor markets reveal that the use of the internet allowed the unemployed to make their job search more efficient [Stevenson, 2008], cutting its duration by 7-25\% [Kuhn, Mansour, 2014; Suvankulov et al., 2012]. ${ }^{6}$ Recruiting websites permit employers and job seekers to automatically filter resumes/vacancies, i.e., to conduct the initial screening of applicants/openings, which considerably cuts relevant costs for both sides [Kuhn, 2014].

The internet's communication function amounts to making communication between employers, job seekers, and employment agencies much simpler and less expensive. Present-day recruitment-relevant communication channels include the following:

- email;

- audio and video conference calls (such as via Skype, etc.) for interview purposes;

- instant messengers for quick communication between job seekers and employers/recruiters;

- websites offering a specialized resume-drafting functionality;

- e-portfolios.

Reduced time and financial costs (which are particularly evident in the case of younger, better educated job seekers [Sakurai, Okudo, 2015]) allow them to apply for a larger number of vacancies, while employers have a larger selection of job candidates. Ultimately, this can lead to reduced information asymmetry and reduced transaction costs for both sides during the recruitment process [Autor, 2001]. Empirical evidence of the higher efficiency of an internet-based job search is provided by the reduced labor attrition rate [Beard et al., 2012], the increased probability of signing employment contracts [Kuhn, Skuterud, 2004], the reduced period of unemployment [Suvankulov et al., 2012], and a smaller share of irrelevant offers [Jansen et al., 2005]. The advantages of using the internet as a communication channel are discussed in [Stevenson, 2003], where the authors analyze data flows emerging over the course of one's job search.

However, the internet's obvious strengths do not completely offset certain liabilities its use involves.

1. Unreliable information. Data about job vacancies or job seekers published on the internet may be incomplete or even incorrect, with only limited opportunities to verify the facts. Accordingly, hiring almost never takes place without personal contact between the job seeker and the employer. As is shown in [Marchal et al., 2005], quantifiable data has the highest demand on recruiting websites and companies do their own screening, which increases information asymmetry between employers and employees along with the companies' recruitment costs.

2. Increased time for job search and candidate selection. The extended range of potential job candidates may slow down their screening. At the same time, the increased number of available job openings can slow down the process of finding the right person or job [Fountain, 2005].

3. Technological development rate. Some job seekers' internet experience may be insufficient to participate in a video conference interview. Thus, the internet ceases to be a potential advantage and turns into a barrier that hinders successful employment. Employers are less likely to encounter such problems, but even in their case the lack of technological competences may become a negative factor.

Quantitative data allows one to measure the internet's popularity as a medium and a tool for recruitment and finding jobs.

\section{Data}

Empirical data for our study consists of the results of enterprise and individual surveys. In the first case, we used the "Interaction between External and Internal Labour Markets" (IEILM) 7 survey conducted in 2010-2014 for the HSE Laboratory for Labour Market Studies. The participants of the annual survey comprised enterprises operating in various sectors of the economy (mining, manufacturing, construction, transport and communications, trade, financial, and other services) with more than 30 employees, which were located in various Russian regions. Educational and medical institutions were excluded from the sample as they are financed predominantly through the public budget. ${ }^{8}$ The final sample comprised

\footnotetext{
${ }^{4}$ The use of the US job vacancies site Monster.com was analyzed in [Brenčič, Norris, 2012].

5 The social network for professionals, LinkedIn, is analyzed in [Garg, Telang, 2011]; a similar research study based on data about retired US military personnel is presented in [Weinburger et al., 2015]; a review of Russian recruiting social media and their usage can be found in [Tikhonova, 2015].

${ }^{6}$ In earlier research [Fountain, 2005; Kuhn, Skuterud, 2000] based on data for the late 1990s - early 2000s, the authors noted that using the internet had no effect on the duration of the job search; a discussion of this fact is presented in [Kuhn, 2014].

For more about the project see: https://www.hse.ru/org/projects/13315049, last accessed on 15.06.2016.

${ }^{8}$ Public sector organizations were excluded due to their lack of freedom to shape their HR policies (including hiring), less appealing work conditions, and lower pay [Gimpelson, Lukyanova, 2006; Sharunina, 2016]
} 
Figure 1. Dynamics of the Use of the Internet and Other Recruitment Channels by Russian Companies in 2010-2014 (\% of all companies)
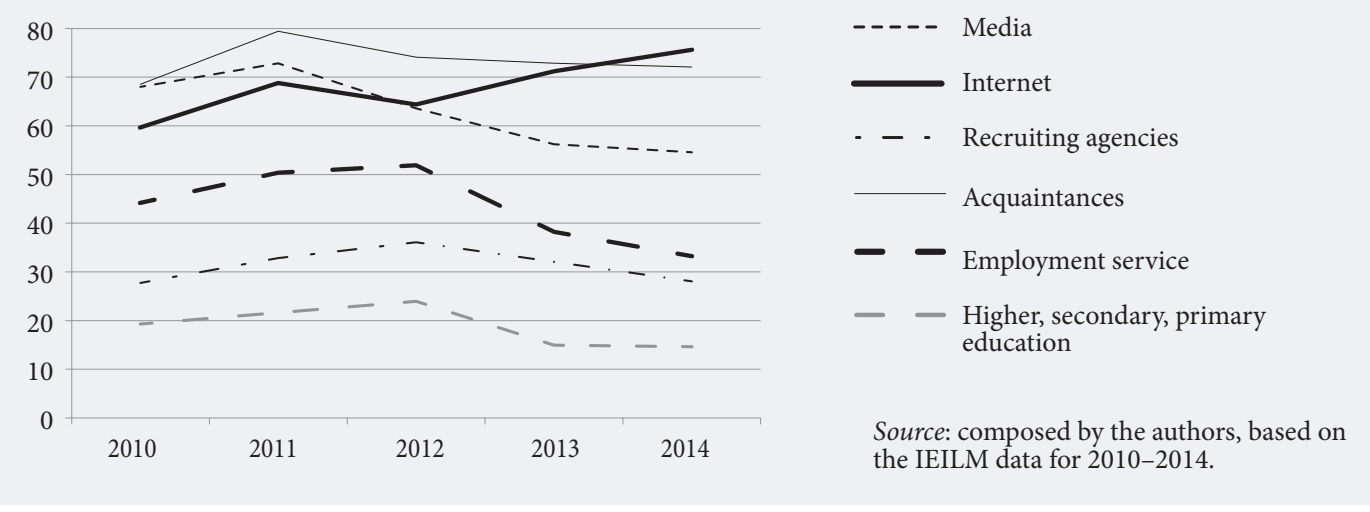

7,847 observations: 1,008 in $2010,1,329$ in $2011,1,505$ in 2012, 2,002 in 2013, and 2,003 in 2014. The weighted averages were calculated on the basis of the total number of enterprises in the relevant sectors of the Russian economy, according to Rosstat data.

To assess companies' use of the internet for recruitment purposes, they were asked "Which recruitment channel does your company use most often to fill managerial/professional vacancies?" One of the answer options was "We try to find candidates ourselves using various internet-based sources". ${ }^{9}$ We assume that by the latter, most of the respondents mean specialized online recruitment services.

Internet usage by job seekers was measured on the basis of Russian Longitudinal Monitoring Survey (RLMS-HSE) ${ }^{10}$ data for 2006-2014. Over the course of the survey, respondents in various Russian regions were asked questions about their employment, income, socio-demographic characteristics, etc. In 2006, "Internet advertising (recruitment websites)" was added to the list of job search channels, and the answer options for the question "How did you find your current job?" were supplemented with "Placed an ad on the internet" and "Saw an ad on the internet". These provided the empirical basis for our study. Data on regional unemployment was taken from Rosstat's "Population Employment Survey". ${ }^{11}$

An analysis of the data about employers and job seekers allowed us to study the use of the internet by both sides of the labor market, and assess the symmetry of their respective perspectives. Below we describe the level of internet use for recruitment and the selection of employees, and then, through the application of descriptive statistics and regression analysis, we identify the factors that increase the probability of corporate and individual use of the internet for these purposes.

\section{The Internet as a Recruitment and Job Search Tool: The Scale and the Dynamics}

The IEILM data allows one to measure the scale and the trends of companies' usage of the internet and other recruitment channels during 2010-2014. If at the beginning of the decade the internet was less popular than conventional media and personal connections, five years later it has achieved full domination (Figure 1). ${ }^{12}$ Note that use of other channels either remained unchanged (acquaintances and private recruiting agencies), or dropped in use (media, public employment services, universities), which gives one ground to speak about their gradual demise.

We look at the groups of employees for which companies use the internet during the hiring process, and what the trends were observed over the five-year period (Figure 2). Most often the internet was used to find professionals, less commonly - managers, manual workers, and junior office workers. During the five years in question the share of companies using the internet to recruit personnel grew in all three of the aforementioned segments; the gap between professionals on the one hand, and managers and lowerskilled workers, on the other, has narrowed from $12-13 \%$ in 2010 to $8 \%$ in 2014.

An analysis of corporate recruitment strategies reveals that the most popular way of recruiting involves using the internet in combination with other channels, first of all, acquaintances. In 2010-2014, the share of companies who used this approach grew from 55\% to $67 \%$, while the share of those making do without

\footnotetext{
9 Other answer options (recruitment channels) included: "We try to find candidates ourselves using publications in printed media"; "We try to find candidates ourselves using recommendations by acquaintances, colleagues, other employees, etc."; "We hire recruitment (HR) agencies"; "We go to the public employment service"; "We go to universities".

${ }^{10}$ For more about the project see: https://www.hse.ru/en/rlms/, last accessed on 15.06.2016.

${ }^{11}$ For more about the project see: http://www.gks.ru/wps/wcm/connect/rosstat_main/rosstat/ru/statistics/publications/catalog/ doc_1140097038766, last accessed on 15.06.2016.

${ }^{12}$ According to the Ancor agency, 93\% of Russian companies used internet-based resources in 2014 [Ancor, 2014]. An earlier study showed that in 2006, only about one third of companies used the internet to fill their vacancies, while personal contacts were the most popular channel [Avraamova et al., 2006].
} 
Figure 2. Use of the Internet as the Primary

Recruitment Channel to Hire Various Personnel Groups (\% of the respondents' answers)

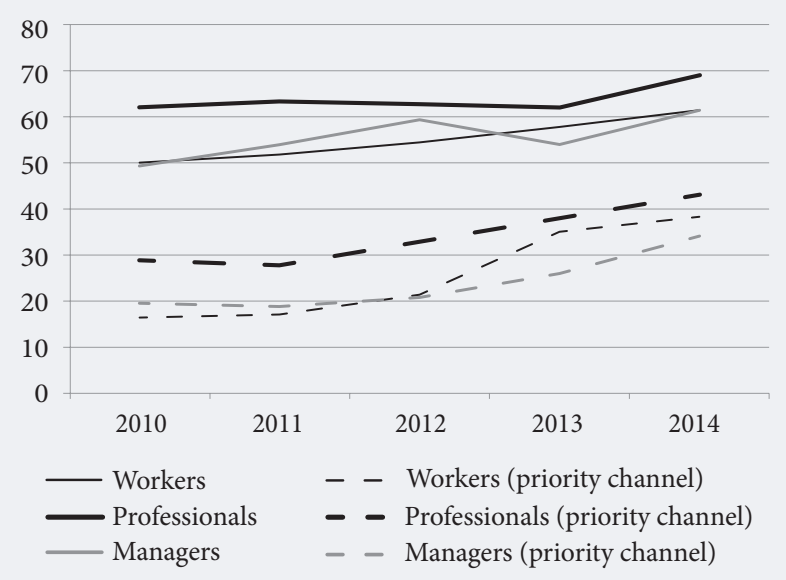

Note: dotted lines indicate that the internet was used as priority recruitment channel to hire certain personnel groups).

Source: composed by the authors, based on IEILM data for 2010-2014.
Figure 3. Application of Different

Recruitment Strategies by Companies

(\% of the respondents' answers)

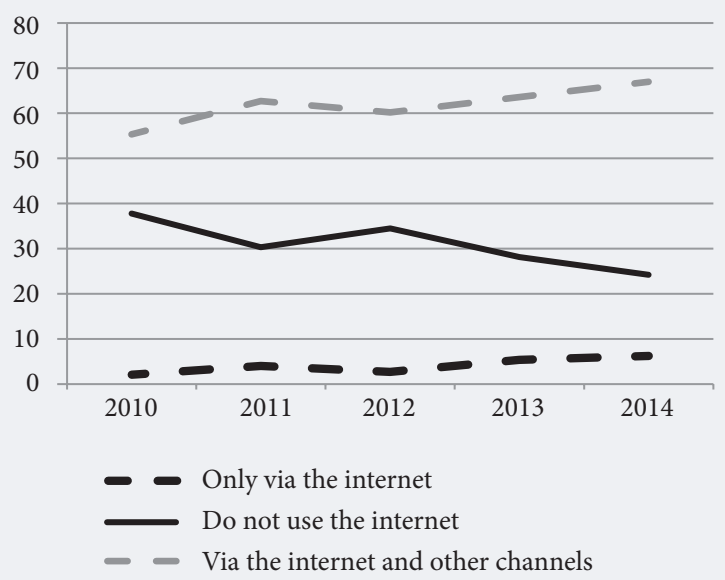

Source: composed by the authors, based on IEILM data for 2010-2014.

the internet dropped from $38 \%$ to $24 \%$ (Figure 3). Exclusively offline strategies were less popular than online ones: a 35\% drop against 29\% growth, respectively. Despite the four-fold growth in the share of companies that recruit their staff via the internet alone, in absolute terms this approach to hiring remains rather unpopular: $1.7 \%$ in 2010 and $6.7 \%$ in 2014.

The extent of using the internet to find jobs was measured on the basis of the RLMS-HSE data for 20062014 (Figure 4). The use of online resources demonstrated high growth, from 13\% to $49 \%$ in eight years, making the internet the third most popular job search channel, with other sources of vacancies either retaining or slightly losing their positions. However, friends' and relatives' help still remains at the top of the list.

The changes in various job search strategies' popularity in some ways reflect the trends in recruitment for employers (Figure 5). A complete refusal to use the internet was less common (a 35\% reduction) than strategies which did imply its use (29\% growth). However, only a small share of job seekers ( $8 \%$ in 2014) relied exclusively on the internet.

About $7.5 \%$ of the respondents said they found their current job via the internet (Table 1). This approach is more common for medium-skilled professionals (10\%), tradesmen (11\%), and unskilled workers (12\%). Sector-wise, light industry (14\%), health and welfare (10\%), and trade (10\%) stand out. Highly skilled professionals, agricultural, and skilled industrial workers find jobs via the internet much less often, along with those employed in mining, heavy industry, agriculture, and public service.

\section{Figure 4. Use of Job Search Channels (\% of all job seekers)}

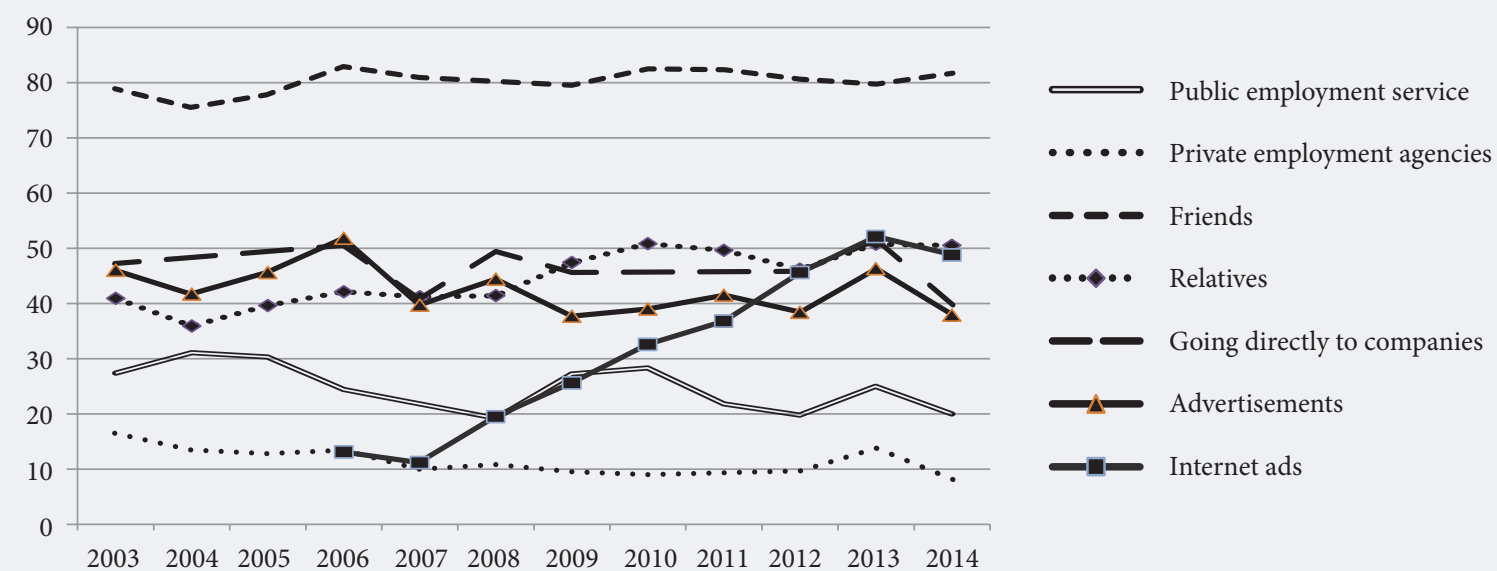

Source: composed by the authors, based on IEILM data for 2003-2014. 


\section{Figure 5. Dynamics of the Popularity of Job Search Strategies (\% of all job seekers)}

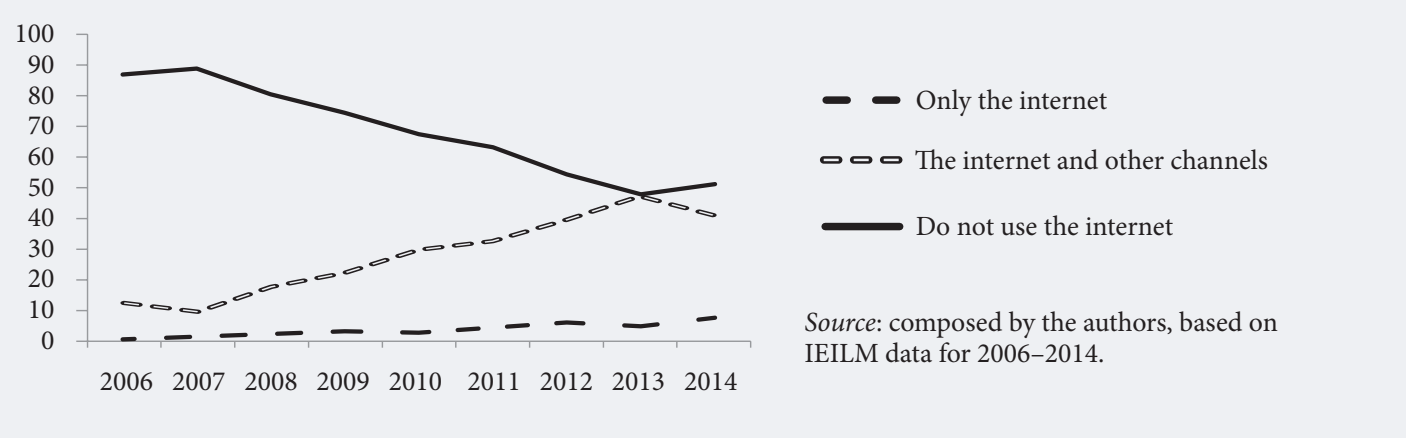

\section{The Use of the Internet for Recruitment Purposes}

Descriptive statistics on companies' use of the internet for recruitment purposes reveal significant discrepancies between various industries (Table 2). The highest interest in the internet as a recruitment channel is demonstrated by financial (skilled and administrative personnel) and trading (all personnel groups) companies; much less interested are construction firms (all personnel groups), together with mining (manual workers), manufacturing (administrative), and transport and communications (administrative) companies, i.e., the more conventional industries. ${ }^{13}$ Differences in internet usage between small, medium, and large companies are negligible.

Companies paying low wages are less likely to use the internet to recruit staff; as for the recruitment of managers, no linear correlation was discovered. Contrary to expectations, the probability of using the internet for recruiting purposes increases along with companies' financial health. Despite the low costs associated with this approach, companies do not see it as a way to cut their recruitment expenditures. Firms headed by young CEOs more often make use of the opportunities offered by the internet, while the level of companies' innovation activity has no appreciable impact upon this indicator. Companies in Moscow and St. Petersburg are the leaders in online recruitment, while small Russian towns lag far behind them.

An econometric analysis of the factors affecting companies' use of the internet for recruitment purposes (Table 3) on the whole confirms the descriptive statistics.

The lack of a correlation between companies' innovation activity and the use of the internet for recruitment purposes suggests such that such practices are quite common in companies' HR policies. Trading and financial firms tend to be more active in this regard, followed by mining and construction enterprises. A possible explanation is that the candidates' specific skills are less important in trade, while automatic screening allows a firm to efficiently select suitable people for subsequent interviews. Also, the internet allows one to cut recruitment costs, which is important in a high-turnover industry. ${ }^{14}$

Practically no differences were discovered between the level of internet usage by small, medium, and large companies, which was not the case regarding the average wages they paid. Firms paying up to

\section{Table 1. Shares of Respondents Who Found Their Current Job on the Internet (\%)}

\begin{tabular}{|l|c|l|c|}
\hline Total & $\mathbf{7 . 5}$ & By sector of economy & \\
\hline By occupation & & Light industry & 14.0 \\
\hline Managers, executives & 6.7 & Mining and heavy industry & 1.6 \\
\hline Highly skilled professionals & 0 & Construction, transport, communications & 6.0 \\
\hline Medium-skilled professionals & 10.1 & Agriculture, fisheries, forest industry & 0 \\
\hline Office workers & 5.4 & Public administration & 1.4 \\
\hline People employed in trade and services & 11.2 & Education, science, culture & 6.1 \\
\hline Skilled agricultural workers & 0 & Health, welfare & 10.2 \\
\hline Skilled manual workers & 3.2 & Trade, household and communal services & 10.3 \\
\hline Skilled machine operators & 4.3 & Finance, insurance & 4.0 \\
\hline Unskilled workers & 12.3 & Other & 5.3 \\
\hline Source: composed by the authors, based on IEILM data for 2014. \\
\hline
\end{tabular}

${ }^{13}$ In 2006, trading and ICT companies used the internet for recruitment purposes most actively, while mining firms were the least active.

${ }^{14}$ According to Rosstat data, in 2014 labor turnover in trade was 90\% higher than the average for the whole economy [Rosstat, 2015b]. 


\section{Table 2. Shares of Companies Who Use the Internet to Recruit Various Personnel Groups (\%)}

\begin{tabular}{|c|c|c|c|c|}
\hline Indicators & Workers & Professionals & Management & Total \\
\hline Average & 62 & 70 & 62 & 76 \\
\hline \multicolumn{5}{|l|}{ Sector of economy } \\
\hline Mining & 42 & 67 & 58 & 76 \\
\hline Manufacturing & 63 & 68 & 55 & 75 \\
\hline Construction & 50 & 58 & 53 & 64 \\
\hline Trade & 72 & 76 & 69 & 80 \\
\hline Transport and communications & 59 & 65 & 52 & 70 \\
\hline Finance & 59 & 78 & 78 & 84 \\
\hline Services & 56 & 69 & 64 & 76 \\
\hline \multicolumn{5}{|l|}{ Number of employees } \\
\hline $30-50$ & 60 & 73 & 63 & 76 \\
\hline $51-100$ & 63 & 67 & 59 & 75 \\
\hline $101-250$ & 61 & 73 & 66 & 72 \\
\hline $251-1000$ & 63 & 70 & 64 & 78 \\
\hline $1000+$ & 59 & 73 & 70 & 77 \\
\hline \multicolumn{5}{|l|}{ Average monthly wage (thousand rubles) } \\
\hline Under 19.9 & 46 & 57 & 50 & 64 \\
\hline $20.0-24.9$ & 59 & 73 & 71 & 81 \\
\hline $25.0-34.9$ & 66 & 73 & 62 & 78 \\
\hline $35.0+$ & 69 & 81 & 68 & 86 \\
\hline \multicolumn{5}{|l|}{ Financial situation } \\
\hline Poor or average & 58 & 66 & 60 & 74 \\
\hline Good & 70 & 77 & 67 & 80 \\
\hline \multicolumn{5}{|l|}{ Innovative $^{\mathrm{I}}$} \\
\hline Yes & 64 & 70 & 63 & 78 \\
\hline No & 61 & 69 & 61 & 77 \\
\hline \multicolumn{5}{|l|}{ Making large investments } \\
\hline Yes & 61 & 69 & 69 & 77 \\
\hline No & 62 & 70 & 61 & 76 \\
\hline \multicolumn{5}{|l|}{ Ownership } \\
\hline Public $^{\mathrm{II}}$ & 33 & 43 & 43 & 55 \\
\hline Private, fully Russian-owned & 63 & 71 & 63 & 77 \\
\hline Private, with international participation & 65 & 75 & 62 & 83 \\
\hline \multicolumn{5}{|l|}{ CEO's age } \\
\hline Under 39 & 65 & 76 & 68 & 82 \\
\hline $40-49$ & 63 & 71 & 64 & 78 \\
\hline $50-59$ & 56 & 62 & 56 & 70 \\
\hline $60+$ & 67 & 74 & 60 & 81 \\
\hline \multicolumn{5}{|l|}{ Location (city) } \\
\hline Moscow or St. Petersburg & 61 & 77 & 71 & 81 \\
\hline 1 million + & 61 & 68 & 60 & 74 \\
\hline $500,000-1$ million & 68 & 75 & 58 & 79 \\
\hline $100,000-500,000$ & 60 & 66 & 60 & 72 \\
\hline 100,000 or fewer & 55 & 54 & 60 & 65 \\
\hline \multicolumn{5}{|c|}{ 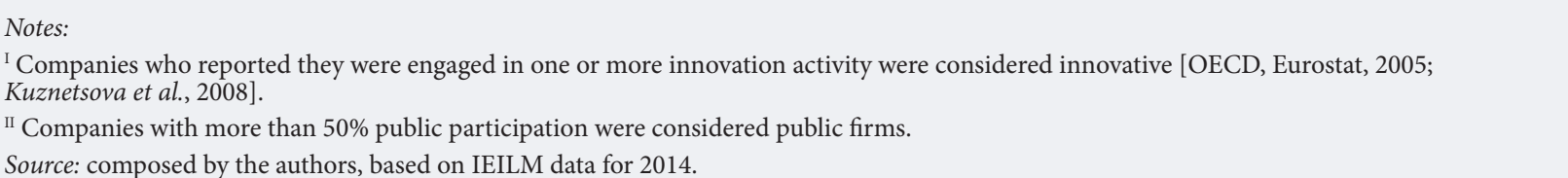 } \\
\hline
\end{tabular}

20,000 rubles a month tend to use online resources much more actively, unlike those paying a higher wage. Public companies use the internet much less often with no appreciable changes in this regard since 2006 [Avraamova et al., 2006]. Another less important factor is the CEO's age. The use of online resources is lower in smaller cities (with populations below 100,000), and higher in medium ones (500,000 - 1 million).

Companies' use of recruitment opportunities offered by the internet is directly connected with their financial situation (indicators such as their balance sheet, the average wages they pay, whether they operate in highly competitive industries) and their interest in hiring highly skilled personnel, but not with their need to cut recruitment costs. Low internet usage by public companies is evidence of their technological inertia and low competitiveness. Ultimately, the less advanced companies tend to hire less advanced and less productive workers. 
Table 3. Factors affecting companies' internet usage, probit model, and dependent variable: using the internet to recruit various personnel groups (\%)

\begin{tabular}{|c|c|c|c|c|}
\hline Indicators & Workers & Professionals & Management & Total \\
\hline \multicolumn{5}{|l|}{ Sector (Manufacturing) } \\
\hline Mining & $-0.245^{\star \star}$ & -0.110 & 0.048 & 0.052 \\
\hline Construction & $-0.100^{*}$ & -0.072 & -0.033 & $-0.108^{\star *}$ \\
\hline Trade & $0.085^{\star \star}$ & $0.067^{*}$ & $0.086^{\star *}$ & 0.042 \\
\hline Transport and communications & -0.005 & 0.044 & -0.063 & -0.009 \\
\hline Finance & -0.043 & $0.115^{\star *}$ & $0.174^{\star * *}$ & 0.069 \\
\hline Services & -0.011 & 0.048 & $0.096^{* *}$ & 0.047 \\
\hline \multicolumn{5}{|l|}{ Number of employees $(30-50)$} \\
\hline $51-100$ & 0.049 & -0.042 & -0.040 & -0.019 \\
\hline $101-250$ & 0.067 & 0.011 & 0.079 & 0.031 \\
\hline $251-1000$ & $0.085^{\star *}$ & 0.000 & 0.014 & 0.027 \\
\hline $1000+$ & 0.114 & 0.070 & 0.083 & 0.063 \\
\hline \multicolumn{5}{|c|}{ Average monthly wage (thousand rubles) (20.0-24.9) } \\
\hline Under 19.9 & $-0.191^{* * *}$ & $-0.142^{* * *}$ & $-0.130^{* * *}$ & $-0.141^{* * *}$ \\
\hline $25.0-34.9$ & $-0.097^{\star *}$ & -0.050 & $0.102^{\star *}$ & -0.012 \\
\hline $35.0+$ & -0.000 & 0.045 & $0.078^{*}$ & 0.045 \\
\hline \multicolumn{5}{|l|}{ Company situation } \\
\hline Good financial situation & $0.102^{\star * *}$ & $0.100^{* * *}$ & $0.067^{\star *}$ & $0.079^{* * *}$ \\
\hline Innovative & -0.012 & -0.018 & -0.019 & -0.037 \\
\hline Making large investments & -0.013 & 0.047 & $0.113^{\star * *}$ & $0.061^{\star}$ \\
\hline \multicolumn{5}{|l|}{ Ownership (Private, fully Russian-owned) } \\
\hline Public & $-0.226^{\star * *}$ & $-0.294^{* * *}$ & $-0.313^{* * *}$ & $-0.335^{\star * *}$ \\
\hline Private, with international participation & -0.014 & -0.018 & $-0.267^{\star * *}$ & -0.052 \\
\hline \multicolumn{5}{|l|}{ CEO's age $(40-49)$} \\
\hline Under 39 & 0.045 & $0.080^{* *}$ & 0.052 & 0.052 \\
\hline $50-59$ & -0.037 & -0.054 & -0.064 & $-0.058^{*}$ \\
\hline $60+$ & 0.020 & 0.012 & 0.027 & -0.007 \\
\hline \multicolumn{5}{|l|}{ Location (1 million + ) } \\
\hline Moscow or St. Petersburg & 0.014 & 0.006 & -0.035 & 0.010 \\
\hline $500,000-1$ million & -0.002 & $0.070^{*}$ & $0.135^{\star * *}$ & $0.097^{* * *}$ \\
\hline $100,000-500,000$ & 0.044 & 0.047 & 0.006 & 0.053 \\
\hline 100,000 or fewer & -0.034 & $-0.154^{\star *}$ & -0.118 & $-0.105^{\star}$ \\
\hline Observations & 1111 & 1137 & 996 & 1164 \\
\hline Pseudo $\mathrm{R}^{2}$ & 0,055 & 0,076 & 0,083 & 0,086 \\
\hline
\end{tabular}

\section{The Use of the Internet to Find Jobs}

The use of the internet to find a job has certain specific features depending on the job seekers' sociodemographic characteristics (Table 4). Young and middle-age cohorts (16-45) tend to more actively use the internet for these purposes, along with people whose education level is above average, and residents of large cities (Moscow, St. Petersburg, regional capitals, and other cities). Studies of the US labor market cite similar data regarding job seekers' education level [Kuhn, Mansour, 2014] and age [Kuhn, Skuterud, 2004].

Over the course of the econometric analysis, we assessed factors affecting internet usage by job seekers (Model 1) and companies (Model 2). In the first case (Table 5), a binary choice probit model was used: the use of the internet to find a job served as dependent variable and the respondents' personal characteristics (age, gender, family status, education, etc.), place of residence, and the year of the survey were used as explanatory variables.

The analysis allowed us to arrive at several major conclusions. Firstly, a higher level of education increases the probability of using the internet to find a job; a possible explanation is the correlation between both these characteristics and computer literacy. On the other hand, age does not affect the likelihood of using the internet: job seekers in various age cohorts are equally likely to make use of online resources. Secondly, the larger the city, the more often its residents try to find jobs online. Thirdly, between 20102014 , the probability of using the internet to find a job grew by $22 \%$. 
Table 4. Shares of People Who Use the Internet to Find Jobs in Various Job Seeker Groups (\%)

\begin{tabular}{|c|c|c|c|}
\hline Total & 48.8 & & \\
\hline Gender & & Education & \\
\hline Male & 44.2 & Below secondary & 37.9 \\
\hline Female & 54.4 & Secondary & 37.5 \\
\hline \multicolumn{2}{|l|}{ Age } & \multirow[t]{2}{*}{ Vocational, below secondary } & \multirow[t]{2}{*}{21,4} \\
\hline $16-19$ & 68.8 & & \\
\hline $20-24$ & 63.0 & \multirow[t]{2}{*}{ Vocational secondary } & \multirow[t]{2}{*}{38.6} \\
\hline $25-29$ & 51.6 & & \\
\hline $30-34$ & 53.2 & Secondary professional & 55.1 \\
\hline $35-39$ & 55.6 & Tertiary & 73.6 \\
\hline $40-44$ & 50.9 & Place of residence & \\
\hline $45-49$ & 29.8 & Moscow, St. Petersburg & 76.7 \\
\hline $50-54$ & 28.8 & Regional capital & 64.3 \\
\hline $55-59$ & 40.6 & City & 52.3 \\
\hline $60-64$ & 25.0 & Town & 14.3 \\
\hline $65+$ & 11.1 & Village & 25.5 \\
\hline
\end{tabular}

In the scope of the second model, we measured how using the internet affected job search success in 2010-2013 (data for 2014 was only used to estimate the probability of finding a job) (Table 5). Actually getting employed served as a binary choice dependent variable (did the respondents who were seeking jobs during the period in question find one during the next period?). The same explanatory variables as those in the first model were used in the second plus the use of the internet to find a job. The calculations confirmed the importance of the latter factor for the model: it increased the probability of finding a job by $4.5 \%$. Studies of other countries' labor markets present similar results: using the internet increased the chances of finding a job by $7.1 \%$ and $12.7 \%$ in Germany and South Korea, respectively [Suvankulov et al., 2012]. The internet allows one to find jobs quicker, and does not rule out using other channels such as asking friends, relatives, acquaintances, etc., for help.

Factors affecting the use of the internet by job seekers and employers show a good match between one another (as far as it is possible to compare them). Both sides of the hiring process prefer to combine various search channels. Companies more often use the internet to recruit professionals, and less often do so when hiring managers and manual workers; similarly, professionals more frequently find jobs via the internet than managers and workers do. Industry-wise, trade uses the internet for recruitment purposes more actively than other sectors of the economy. Job seekers and companies in small towns significantly lag behind large cities in this respect.

\section{Conclusion}

The demand for online recruitment and job placement resources significantly increased over the last five to ten years: the share of companies who use the internet to recruit personnel has grown from $60 \%$ in 2010 to $76 \%$ in 2010-2014, while the share of job seekers using the internet to find employment in 20062014 increased from 13\% to $49 \%$. On the whole, such practices can be considered established and routine on the Russian labor market, i.e., it would be more correct to speak about the evolution of (as opposed to a revolution in) recruiting. At the same time, the internet did not replace the main channel for finding jobs and personnel alike (i.e., friends and acquaintances or social networks), but rather supplemented it. All labor market players use recruitment platforms not so much to cut costs (as maintains [Autor, 2001]), as to find better workers and better jobs [Sakurai, Okudo, 2015].

Mutual complementarity was discovered between personnel hired via the internet, and vacancies typically filled this way. Online mechanisms are most commonly used by private Russian-owned trading and financial companies paying good wages and enjoying a healthy financial position, located in medium and large cities. The internet is more often used to recruit professionals than lower-skilled workers (who are not sufficiently represented online), or managers (hiring them involves a comprehensive assessment of candidates and requires personal contact). The high demand for online recruiting resources by trading firms can be explained by the fact that such jobs do not require specific skills, so companies can use mechanisms for the automatic screening of applicants. Public companies (who tend to lag in this area) remain highly inertial regarding the application of innovative techniques and work procedures. Individuals with higher or secondary professional education residing in Moscow, St. Petersburg, and regional capitals use the internet to find jobs more actively than others do, which increases their chances of finding suitable employment. 


\section{Table 5. Factors Affecting the Use of the Internet to Find Jobs (Model 1), and the Probability of Finding Them (Model 2) (probit model)}

\begin{tabular}{|c|c|c|}
\hline \begin{tabular}{lc|} 
Explanatory variables & Dependent variable \\
\end{tabular} & $\begin{array}{l}\text { Use of the internet to find } \\
\text { jobs }\end{array}$ & $\begin{array}{c}\text { Probability of finding } \\
\text { a job }\end{array}$ \\
\hline & (1) & (2) \\
\hline Use of the internet to find a job & & $0.0454^{* *}$ \\
\hline \multicolumn{3}{|l|}{ Socio-demographic characteristics } \\
\hline Age & 0.0031 & $-0.0093^{*}$ \\
\hline Age (square) & $-0.0001^{\star *}$ & 0.0001 \\
\hline Gender $($ female $=1)$ & -0.0131 & -0.0087 \\
\hline Family status (married $=1$ ) & $0.0508^{\star *}$ & 0.0115 \\
\hline Number of children younger than 18 & $-0.0215^{*}$ & 0.0008 \\
\hline Student & $0.1047^{\star \star}$ & $-0.0886^{\star *}$ \\
\hline Pensioner & -0.0480 & 0.0740 \\
\hline \multicolumn{3}{|l|}{ Labor market status } \\
\hline Unemployment level in the region & 0.0180 & -0.0403 \\
\hline Registered at the public employment service & $-0.0579^{*}$ & $0.1287^{\star *}$ \\
\hline Unemployed for more than a year & -0.0641 & 0.0526 \\
\hline \multicolumn{3}{|l|}{ Education (below secondary) } \\
\hline Secondary & $0.1305^{\star \star}$ & -0.0100 \\
\hline Vocational, below secondary & 0.0018 & 0.0356 \\
\hline Vocational secondary & $0.0730^{\star *}$ & 0.0410 \\
\hline Secondary professional & $0.2199^{* *}$ & 0.0219 \\
\hline Tertiary & $0.3091^{\star *}$ & -0.0329 \\
\hline Post graduate & $0.3317^{\star \star}$ & -0.0806 \\
\hline \multicolumn{3}{|l|}{ Place of residence (Moscow, St. Petersburg) } \\
\hline Regional capital & $-0.1158^{\star *}$ & -0.0071 \\
\hline Regional center & $-0.2255^{\star *}$ & 0.0214 \\
\hline Town & $-0.3257^{\star *}$ & 0.0462 \\
\hline Village & $-0.3902^{\star *}$ & 0.0320 \\
\hline \multicolumn{3}{|l|}{ Federal District (Central) } \\
\hline Southern & -0.1100 & 0.1307 \\
\hline North-Western & -0.0264 & 0.0546 \\
\hline Far Eastern & -0.0394 & $0.2129^{*}$ \\
\hline Siberian & -0.1121 & 0.1719 \\
\hline Urals & 0.0139 & 0.0939 \\
\hline Volga & $-0.1093^{\star}$ & 0.0969 \\
\hline North Caucasus & $-0.3827^{\star}$ & 0.4378 \\
\hline \multicolumn{3}{|l|}{ Year (2010) } \\
\hline 2011 & 0.0350 & $-0.0649^{*}$ \\
\hline 2012 & $0.1250^{\star *}$ & -0.0862 \\
\hline 2013 & $0.1942^{\star *}$ & $-0.1062^{\star}$ \\
\hline 2014 & $0.2212^{\star \star}$ & \\
\hline Constant & -0.2054 & 0.5252 \\
\hline Number of observations & 4096 & 3565 \\
\hline Pseudo $\mathrm{R}^{2}$ & 0.2121 & 0.0271 \\
\hline
\end{tabular}

The obtained results allow us to map areas where online recruitment mechanisms are likely to develop further. Firstly, the increased use of such functionality by older (due to the ageing of the current audience) and less educated job seekers will be fuelled by the advancement of the mobile internet, and the adaptation of online services for use on smartphones. Secondly, public companies paying lower wages will be more actively recruiting low-skilled workers via the internet, due to development of, and easier access to relevant resources. Thirdly, the digitalization of conventional recruitment channels is likely to continue, primarily due to advertising in mass media and the public employment service's and private recruiting agencies' efforts. Relevant good examples include the online vacancy database at TrudVsem.ru and similar portals maintained by regional employment services. Even such a popular source of information about jobs as relatives and acquaintances is changing due to the advancement of social networks and online messenger services.

This paper was written in the scope of the "Inequality on the Labour Market" project implemented by the Laboratory for Labour Market Studies in the framework of the HSE Basic Research Programme. 


\section{References}

Ancor (2014) Rekrutment $v$ kompaniyakh Rossii. Vzglyad rabotodatelei [Recruitment in the companies of Russia. The view of employers]. Moscow: Ancor. Available at: https://ancor.ru/f/1/client/Recruitment\%20v\%20Rossii.pdf, accessed 17.02.2016 (in Russian).

Autor D.H. (2001) Wiring the Labor Market. Journal of Economic Perspectives, vol. 15, no 1, pp. 25-40.

Avraamova E., Gurkov I., Karpukhina G., Levinson A., Mikhailyuk M., Polushkina E., Stuchevskaya O. (2006) Trebovaniya rabotodatelei $k$ sisteme professional'nogo obrazovaniya [Requirements of employers to the vocational education system] (eds. T. Klyachko, G. Krasnova), Moscow: MAKS Press (in Russian).

Beard T.R., Ford G.S., Saba R.P., Seals Jr. R.A. (2012) Internet use and job search. Telecommunications Policy, vol. 36, no 4, pp. 260-273.

Brenčič V., Norris J.B. (2012) Employers' On-Line Recruitment and Screening Practices. Economic Inquiry, vol. 50, no 1, pp. 94-111.

Denisova I., Lazareva O. (2006) Naem ili pereobuchenie: opyt rossiiskikh predpriyatii [Recruitment or retraining: The experience of Russian enterprises] (HSE Preprint WP3/2006/11). Moscow: HSE (in Russian).

Fountain C. (2005) Finding a Job in the Internet Age. Social Forces, vol. 83, no 3, pp. 1235-1262.

Garg R., Telang R. (2012) To be or not to be linked on LinkedIn: Job search online social network (Heinz College Working Paper, June 2012), Pittsburgh, PA: Carnegie Mellon University.

Gimpelson V., Lukyanova A. (2006) Byt' byudzhetnikom v Rossii: udachnyi vybor ili neschastnaya sud'ba? [To be a budgetary in Russia: A successful choice or an unhappy fate?]. Ekonomicheskii zhurnal Vysshei shkoly ekonomiki [HSE Economic Journal], vol. 10, no 4, pp. 557-589 (in Russian).

HSE (2016) Indikatory informatsionnogo obshchestva: 2016. Statisticheskii sbornik [Information Society Indicators: 2016. Data Book], Moscow: HSE (in Russian).

Jansen B.J., Jansen K.J., Spink A. (2005) Using the web to look for work: Implications for online job seeking and recruiting. Internet Research, vol. 15, no 1, pp. 49-66.

Jovanovic B. (1979) Job Matching and the Theory of Turnover. Journal of Political Economy, vol. 87, no 5, pp. 972-990.

Kuhn P. (2014) The Internet as a labor market matchmaker. IZA World of Labor, no 18. Available at: https://wol.iza.org/ uploads/articles/18/pdfs/internet-as-a-labor-market-matchmaker.pdf?v=1, accessed 17.02.2016.

Kuhn P., Mansour H. (2014) Is Internet Job Search Still Ineffective? The Economic Journal, vol. 124, no 581, pp. 12131233.

Kuhn P., Skuterud M. (2000) Job search methods: Internet versus traditional. Monthly Labour Review, no 123, pp. 3-11.

Kuhn P., Skuterud M. (2004) Internet Job Search and Unemployment Durations. American Economic Review, vol. 94 no 1, pp. 218-232.

Kuznetsova I., Gosteva S., Gracheva G. (2008) Metodologiya i praktika statisticheskogo izmereniya innovatsionnoi deyatel'nosti v ekonomike Rossii: sovremennye tendentsii [Methodology and practice of statistical measurement of innovative activity in the Russian economy: Current trends]. Voprosy statistiki, no 5, pp. 30-46 (in Russian).

Marchal E., Mellet K., Rieucau G. (2005) Job Board Toolkits: Internet Matchmaking and the Transformation of HelpWanted Ads (Centre d'études de l'emploi Working Paper no 50), Noisy-le-Grand: Centre d'études de l'emploi.

Nakamura A.O., Shaw K.L., Freeman R.B., Nakamura E., Pyman A. (2009) Jobs Online. Studies of Labor Market Intermediation (ed. D.H. Autor), Cambridge, MA: National Bureau of Economic Research, pp. 27-65.

Naryshkina A. (2007) Modelirovanie protsessa poiska raboty pri perekhode ot ucheby $k$ rabote [Modeling the process of job search in the transition from study to work] (HSE Preprint WP15/2007/03), Moscow: HSE (in Russian).

OECD, Eurostat (2005) Oslo Manual. Guidelines for Collecting and Interpreting Innovation Data ( ${ }^{\text {rd }}$ ed.), Paris: OECD, Eurostat.

Roshchin S., Markova K. (2004) Vybor kanalov poiska raboty na rossiiskom rynke truda [Choice of job search channels on the Russian labor market] (EERC Preprint 04/05), Moscow: Economics Education and Research Consortium (in Russian).

Roshchin S., Travkin P. (2015) Dopolnitel'noe professional'noe obuchenie na rossiiskikh predpriyatiyakh [JobRelated Training on Russian Enterprises]. Zhurnal Novoi ekonomicheskoi assotsiatsii [Journal of the New Economic Association], no 2, pp. 150-171 (in Russian).

Rosstat (2015a) Vyborochnoe nablyudenie po voprosam ispol'zovaniya naseleniem informatsionnykh tekhnologii $\mathrm{i}$ informatsionno-telekommunikatsionnykh setei za $2014 \mathrm{~g}$. [Selective observation on issues of population use of information technologies and information and telecommunications networks for 2014], Moscow: Rosstat (in Russian).

Rosstat (2015b) Trud i zanyatost' v Rossii: 2015 [Labor and Employment in Russia: 2015], Moscow: Rosstat. Available at: http://www.gks.ru/free_doc/doc_2015/trud15.pdf, accessed 07.04.2016 (in Russian).

Sakurai K., Okudo Y. (2015) Job Seeker Trends 2015, Boston, MA: Boston Consulting Group.

Sharunina A. (2016) Gde byudzhetniku zhit' khorosho: analiz mezhsektornykh razlichii v oplate truda v regionakh Rossii [Where Do Public Workers Live Well? Public-Private Wage Gaps in Russias Regions]. Zhurnal Novoi ekonomicheskoi assotsiatsii [Journal of the New Economic Association], no 2, pp. 105-128 (in Russian).

Stevenson B. (2003) The Internet, Job Search, and Worker Mobility, Stanford, CA: Stanford University.

Stevenson B. (2008) The Internet and Job Search (NBER Working Paper 13886), Cambridge, MA: National Bureau of Economic Research.

Stuken T. (2008) Effektivnost' ispol'zovaniya sotsial'nykh setei pri trudoustroistve [Efficiency of the use of social networks in job placement]. Vestnik Omskogo universiteta (Ekonomika) [Herald of Omsk University (Series "Economics")], no 3, pp. 70-75 (in Russian)

Suvankulov F., Lau Chi Keung M., Ho Chi Chau F. (2012) Job search on the internet and its outcome. Internet Research, vol. 22, no 3, pp. 298-317.

Tikhonova I. (2015) Novye vozmozhnosti rekrutinga XXI veka [New opportunities for recruiting the XXI century]. Nauchnyi almanakh (Sotsiologicheskie nauki) [Scientific almanac (Sociological sciences)], no 7, pp. 1277-1280 (in Russian).

Weinburger C.M., Strider S.H., Vengrouskie E.F. (2015) Social Media Job Searches and the Strength of Veteran Ties. Human Resource Management Research, vol. 5, no 6, pp. 133-153.

Yakubovich V. (2002) Instituty, sotsial'nye seti i rynochnyi obmen: Podbor rabotnikov i rabochikh mest v Rossii [Institutions, social networks and market exchange: Selection of workers and jobs in Russia]. Ekonomicheskaya sotsiologiya: Novye podkhody $k$ institutsionalnomu i setevomu analizu [Economic Sociology: New Approaches to Institutional and Network Analysis] (ed. V.V. Radaev), Moscow: ROSSPEN, pp. 210-251 (in Russian). 